\title{
Biting Midges of the Forcipomyia (Forcipomyia) argenteola group in southern South America, with description of a new species and a key to the Neotropical species (Diptera: Ceratopogonidae)
}

\author{
Pablo I. Marino \& Gustavo R. Spinelli \\ División Entomología, Museo de La Plata, Paseo del Bosque s/n, 1900 La Plata, Argentina; \\ pmarino@fcnym.unlp.edu.ar; spinelli@fcnym.unlp.edu.ar
}

Received 18-V-2007. Corrected 16-XI-2007. Accepted 29-IV-2008.

\begin{abstract}
A new species of the Forcipomyia (Forcipomyia) argenteola group, $F$. $(F$.) donatoi, is described and illustrated from males and females collected in several localities of northern Argentina and in Paraguay. The new species is compared with the similar congeners $F$. $(F$.) marini and $F$. (F.) uramaensis, both from Venezuela. The following three species: Forcipomyia $(F$.) argenteola, $F$. $(F$.) calatheae and $F$. $(F$.) quatei are recorded for the first time from Argentina, and a key is presented for the identification of the seven Neotropical species of the group. Rev. Biol. Trop. 56 (2): 789-794. Epub 2008 June 30.
\end{abstract}

Key words: Forcipomyia argenteola group, new species, new records, key, Neotropical region.

Forcipomyia Meigen, a worldwide genus, is one of the most species-rich in the family Ceratopogonidae, with many species being important pollinators of tropical and subtropical cultivated plants (Winder 1977, Young 1986, Martínez et al. 2000).

Borkent and Spinelli (2000), in their catalog of the New World ceratopogonids south of the United States of America, listed 33 species of subgenus Forcipomyia (Forcipomyia) for the region. Of this number, the following six belong to the Forcipomyia argenteola group, and are mostly distributed in northern South America and Central America: F. argenteola Macfie from eastern Brazil, F. quatei Wirth from USA to northeastern Brazil, $F$. calatheae Wirth from Dominica, Colombia and eastern Brazil, $F$. youngi Wirth from Panama, Costa Rica and Ecuador, and F. marini Spinelli and Dippolito and $F$. uramaensis Spinelli and Dippolito, both from Venezuela. No further species in this group have been subsequently described.
During the past 15 years, several collecting trips to Paraguay and northern Argentina were undertaken, resulting in a large series of adults of the subgenus Forcipomyia (Forcipomyia) deposited in the collection of the Museo de La Plata, Argentina. The purpose of this paper is to give the first results of the study of these new collections, describing a new species and recording for the first time from this area three species of the Forcipomyia argenteola group, as well as to provide an identification key to the seven Neotropical species of the group.

\section{MATERIALS AND METHODS}

Specimens were slide mounted in Canada balsam and examined, measured and drawn using a binocular compound microscope with attached camera lucida. Types of the new species are deposited in the collection of the Division Entomología, Museo de La Plata, Argentina (MLP). 
Terms for structures follow those used in the Manual of Nearctic Diptera (McAlpine et al. 1981). Terms for wing veins follow the system of the Manual of Nearctic Diptera, with modifications proposed by Szadziewski (1996).

\section{RESULTS}

\section{Key to the Neotropical species}

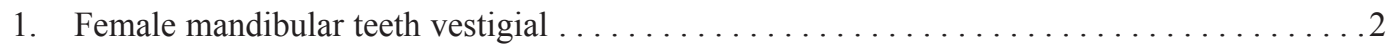

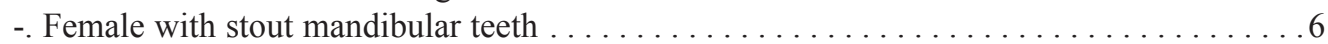

2. Abdomen without broad dark brown scales; femora and tibiae without broad scales, entirely

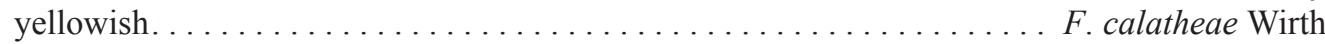
-. Abdomen with broad dark brown scales; femora and tibiae with some broad scales . . . . .3

3. Flagellomere 91.8 times longer than flagellomere 8 ; antennal ratio 1.12; hindtarsal ratio $0.50-0.55$; spermathecae ovoid, tapering to slender opening $\ldots \ldots \ldots \ldots \ldots \ldots \ldots$

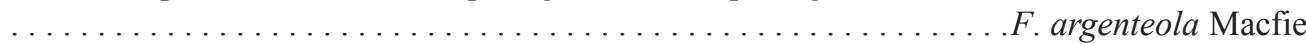
-. Flagellomeres 8 and 9 similar in length; antennal ratio 0.61-0.80; hindtarsal ratio 0.61-0.80; spermathecae oval, not tapering to slender opening $\ldots \ldots \ldots \ldots \ldots \ldots \ldots \ldots \ldots \ldots \ldots \ldots \ldots \ldots \ldots$

4. Spermathecae lightly sclerotized, very large (longest measuring $130 \mu$ long); costal ratio 0.45 ................................ . uramaensis Spinelli \& Dippolito -. Spermathecae heavily sclerotized, smaller (longest measuring $98 \mu$ long or less); costal ratio

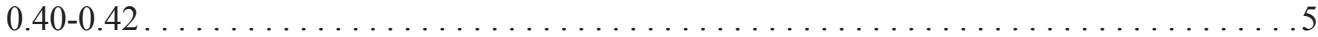

5. Hindfemur dark brown with base and extreme apex paler, narrow bases of fore and midfemora dark brown; pleura mainly dark brown; flagellomeres 1-8 pale, flagellomere 8 slightly shorter than flagellomere 9; gonostylus pale except broad tip dark brown ....... F. donatoi $\mathrm{n}$. $\mathrm{sp}$. -. Hindfemur pale brown, with narrow subapical dark brown ring, narrow bases of fore and midfemora pale; pleura mainly yellow; flagellum uniformly brown, flagellomere 8 slightly longer than flagellomere 9; gonostylus entirely pale

F. marini Spinelli \& Dippolito

6. Female mandible with about 20 small teeth; respiratory horn of pupa slender, with 12-15 spiracles; larval head unicolorous pale brown ............... quatei Wirth -. Female mandible with about 12-15 stout teeth; respiratory horn of pupa globular, with 20-25 spiracles; larval head very dark brown toward mouth............... youngi Wirth

Forcipomyia (Forcipomyia) donatoi, sp. nov. (Figs. 1-12)

Diagnosis. Only species of the argenteola group with the hindfemur dark brown except its base and extreme apex pale, and the fore and midfemora with narrow, brown basal rings.

\section{Description of male}

Head. Dark brown. Eyes bare, broadly abutting medially for length of 5 ommatidia.
Flagellum of antenna (Fig. 1) brown with plume setae well developed, flagellomeres 1-9 at least partially fused, 10-13 elongate; AR $1.12(1.07-1.16, \mathrm{n}=11)$. Palpus (Fig. 2) dark brown; third segment moderately swollen at base, progressively tapering, with deep sensory pit at swollen portion opening by rounded pore, segments 4-5 separate; PR 3.44 $(2.95-3.71, \mathrm{n}=11)$.

Thorax. Dark brown. Scutellum with insertions of 15 stout setae, about 15 smaller ones. 

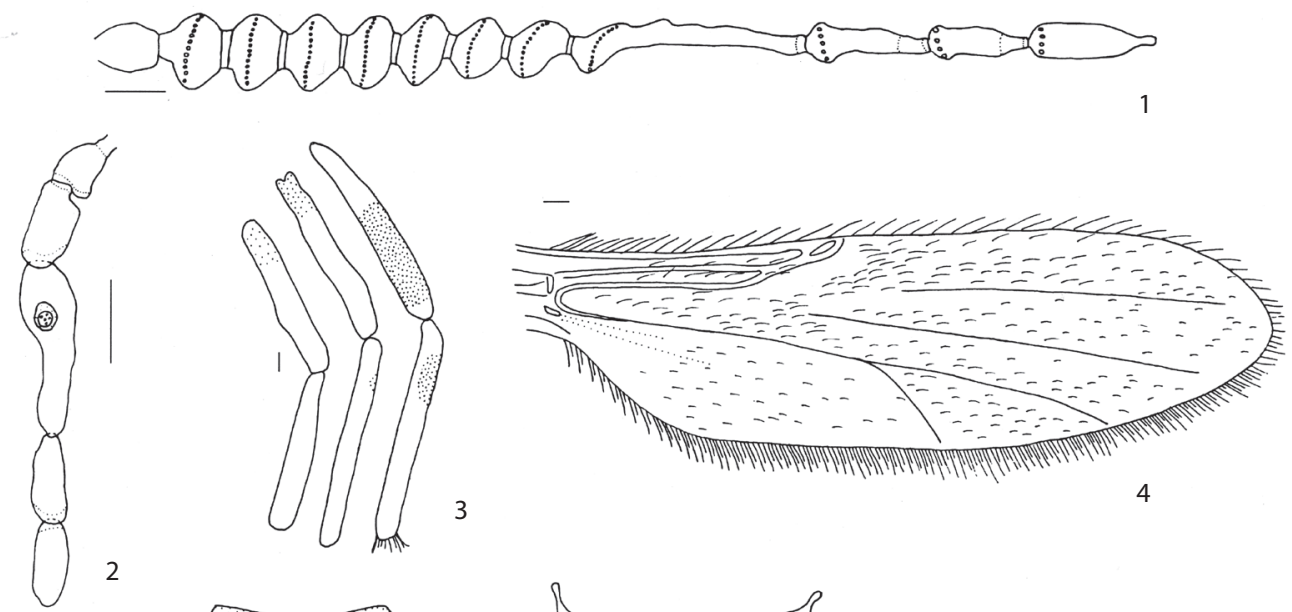

2
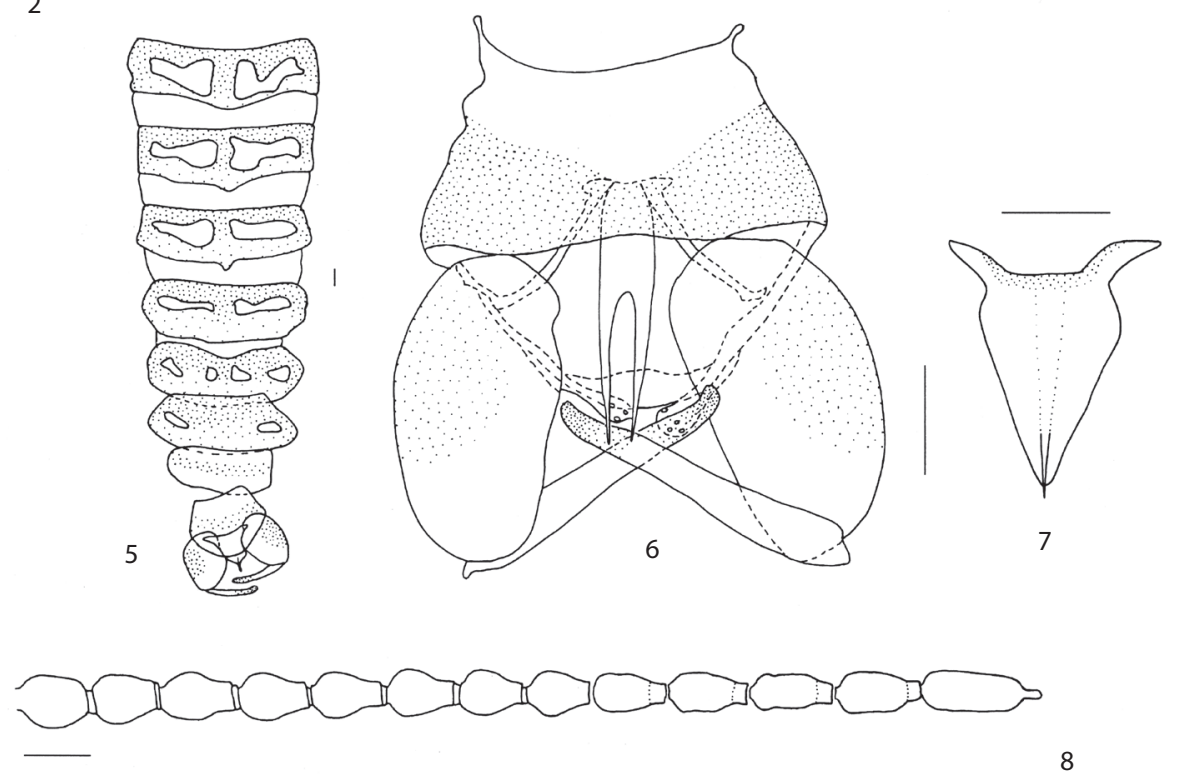

8

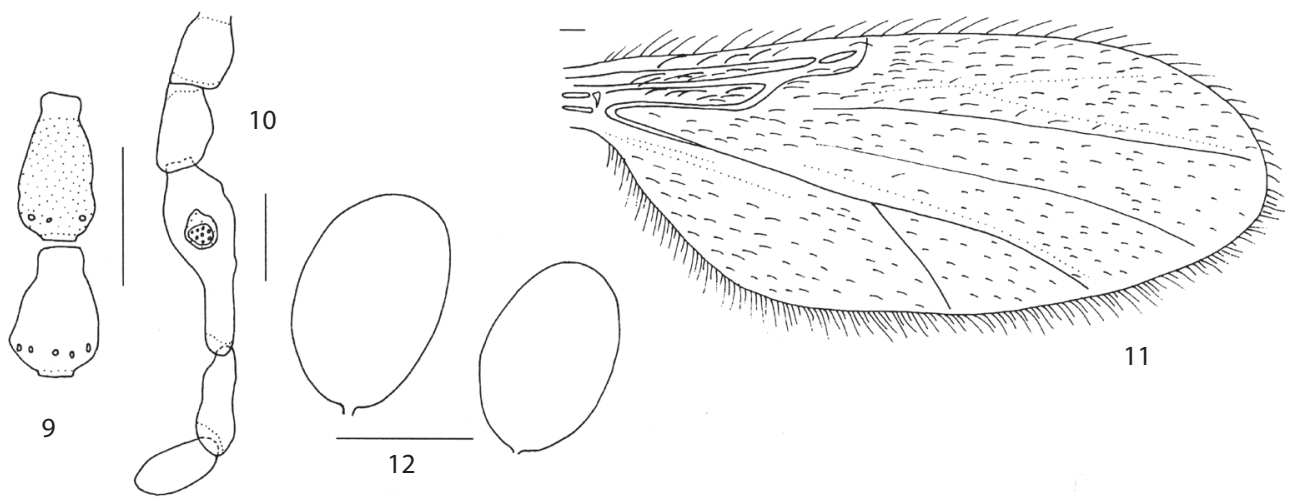

Figs. 1-12. Forcipomyia (F.) donatoi sp. nov. 1-7, male, 8-12, female. 1. Flagellum. 2. Maxillary palpus. 3. Legs (left to right: fore, mid, hind). 4. Wing. 5. Abdominal terga. 6. Genitalia (aedeagus removed). 7. Aedeagus. 8. Flagellum. 9. Flagellomeres 8-9. 10. Maxillary palpus. 11. Wing. 12. Spermathecae. Scale bars $=0.05 \mathrm{~mm}$. 
Legs (Fig. 3) pale brown except coxae and trochanters dark brown, hindfemur dark brown except base and extreme apex paler, hindtibia with subbasal, small dorsal dark spot; base of fore and midfemora brown (more evident on midleg), midtibia with subbasal, very small dark spot; femora and tibia with appresed striated brown scales; ventral palisade setae on tarsomeres 1-3 in all legs; hindtibial spur yellowish, length slightly shorter than width of hindtibia at midlength; hindtibial comb with two rows of spines, apical row with 8-9 spines, subapical row with 12-13 spines; prothoracic TR $0.86(0.83-0.89, \mathrm{n}=11)$, mesothoracic TR $0.68(0.62-0.73, \mathrm{n}=13)$, metathoracic TR 0.64 (0.59-0.69, $\mathrm{n}=13)$; claws slender, curved; empodia present. Wing (Fig. 4) brownish, with abundant long decumbent macrotrichia, darker anteriorly, small yellow spot at end of costa; first radial cell obliterated, second radial cell well-developed, triangular; wing length $1.42(1.26-1.54, \mathrm{n}=13) \mathrm{mm}$; breadth 0.46 $(0.40-0.50, \mathrm{n}=13) \mathrm{mm}$; CR $0.40(0.39-0.42, \mathrm{n}$ $=13)$. Halter pale.

Abdomen (Fig. 5). Tergites 2-7 brown with two lateral yellowish patches, tergite 8 almost entirely yellowish. Genitalia (Fig. 6): tergite 9 short, not extending to apex of gonocoxite, posterior margin rounded; cercus short, extending beyond margin of tergite 9; sternite 9 broad, with shallow posteromedial excavation, proximal $1 / 2$ yellowish, distal $1 / 2$ dark brown. Gonocoxite moderately stout, 1.9 times longer than greatest breadth, yellowish except mesolateral portion brown; gonostylus pale except broad tip dark brown, slightly shorter than gonocoxite, nearly straight, tip barely curved. Parameres joined at base, fused portion extending to $1 / 2$ of total length, distal processes narrowing to pointed tip. Aedeagus (Fig. 7) nearly triangular with sharp pointed tip, 1.6 times longer than basal breadth; poorly sclerotized except basal arch, the later low, almost straight; basal arms well developed, directed anterolaterally.

\section{Description of female}

Head. dark brown. Antenna with proportions of flagellomeres as shown in Fig. 8; flagellomeres 1-8 pale brown, slightly longer than broad, vasiform, flagellomeres 9-13 brown except apices pale; flagellomere 8 slightly shorter than flagellomere 9 (Fig. 9); AR 0.81 (0.72-0.87, $\mathrm{n}=20)$. Palpus (Fig. 10) dark brown with third segment, swollen for basal $1 / 2$ with deep sensory pit near midlength; segments 4, 5 separate, its combined similar in length to segment 3; segment 5 rounded; PR $2.79(2.57-3.20, \mathrm{n}=15)$. Mandible poorly developed, without teeth.

Thorax. Dark brown; scutellum with insertions of 15 stout setae, about 20 smaller ones; pleura mainly dark brown with few yellowish areas. Legs pale brown, hindfemur dark brown except base and extreme apex paler, base of fore and midfemora brown, hindtibia with subapical dorsal dark spot, not abutting ventral side; tarsomeres 1-3 with ventral palisade setae in all legs; hindtibial comb with two rows of spines, apical row with 9-10 spines, subapical row with 14-15 spines; prothoracic TR $0.95(0.78-1.00, \mathrm{n}=20)$, mesothoracic TR $0.77(0.70-0.86, \mathrm{n}=19)$, metathoracic TR 0.71 $(0.64-0.79, \mathrm{n}=19)$; claws curved. Wing (Fig. 10) darker along anterior margin, especially on costa; small pale spot just beyond end of costa; first radial cell obliterated, second well formed, triangular; cubital fork slightly distal to level of end of costa; wing length 1.34 (1.12-1.48, $\mathrm{n}=$ 18) $\mathrm{mm}$; breadth $0.58(0.50-0.66, \mathrm{n}=19) \mathrm{mm}$; CR $0.42(0.41-0.43, \mathrm{n}=18)$. Halter pale.

Abdomen. Brown, covered with abundant narrow striated scales, especially on pleura. Tergites 1-7 dark brown. Segments 8-10 pale brown. Two spermathecae elongate, ovoid without neck, unequal, measuring $91(80-98, \mathrm{n}=14)$ by $59(48-72, \mathrm{n}=14) \mu$ and $77(70-82 \mathrm{n}=14)$ by $49(44-60, \mathrm{n}=14) \mu$ (Fig. 12). Cercus pale.

Distribution. Northeastern Argentina (Formosa, Misiones and Corrientes provinces), Paraguay. 
Types. Holotype male, allotype female, Paraguay, Dept. Presidente Hayes, $5 \mathrm{~km} \mathrm{E}$ Rojas Sanchez, 14-V-1986, R. Woodruff, UV light trap (MLPA). Paratypes 12 males, 19 females, as follows: same data as holotype, 6 males, 5 females; Argentina, Formosa prov., Estancia La Marcela, $35 \mathrm{~km}$ E El Colorado, 27/28-VII-2003, J. Williams, 5 males, 7 females, at light; Misiones prov., Corpus, VII-2001, G. Spinelli, 1 female, CDC; same data except Posadas, 3-X-2001, 4 females; Corrientes prov., Santa Tecla, 5-IX-2001, G. Spinelli, 1 male, 2 females, CDC.

\section{DISCUSSION}

Taxonomic Discussion. Males and females were collected at the same locality and date. The abdominal pigmentation of terga of the male and female differed somewhat, being a distinctive pattern in the male, but absent in the female.

This new species resembles two species from Venezuela described by Spinelli and Dippolito (1995), F. (F.) marini and F. (F.) uramaensis. The later species, which is only known from female specimens, shares with $F$. $(F$.) donatoi the pigmentation pattern of flagellomeres and abdominal terga, but the spermathecae are larger and lightly sclerotized, the fore and midlegs are entirely yellowish, the hind femur is mostly yellowish with a subapical, broad dark brown ring and the costal ratio is larger. Forcipomyia $(F$.) marini differs from the new species by the following characters: flagellomeres of female entirely brown, flagellomere 8 slightly longer than flagellomere 9, hindfemur mostly yellowish with a subapical, narrow dark brown ring, pleura mainly yellow, absence of abdominal pattern of pigmentation and gonostylus entirely pale.

Etymology. This species is named after Dr. Mariano Donato, specialist of Chironomidae of the Museo de La Plata, in recognition of his valuable help collecting ceratopogonids.

\section{NEW RECORDS}

\section{Forcipomyia $(F$.$) argenteola Macfie$}

F. (F.) argenteola Macfie, 1939: 146 (female; Brazil); Lane, 1947: 163 (male, larva, pupa; Brazil); Wirth, 1982: 572 (diagnosis; Brazil); Borkent and Spinelli, 2000: 14 (in Neotropical catalog; distrib.).

Specimens examined. Argentina, Misiones prov., Puerto Iguazú, 21/27-X-2006, C. Cazorla, 1 male, at light. Paraguay, Itapúa, Carmen del Paraná, 20-V-1996, G. Spinelli, 1 male; Itapúa, Bella Vista, 6/7-VI-2000, A. Ortiz - D. Lopez, 1 male, CDC.

Distribution. Brazil, Paraguay, Argentina (Misiones province).

\section{Forcipomyia $(F$.$) calatheae Wirth$}

F. (F.) calatheae Wirth, 1982: 573 (female, male, pupa, larva; Brazil, Colombia, Dominica); Borkent and Spinelli, 2000: 14 (in Neotropical catalog; distrib.).

Specimens examined. Argentina, Salta prov., Río Juramento y ruta nacional $\mathrm{N}^{0}$ 9, 8-VIII-1980, G. Spinelli, 2 males, 1 female, at light; Santiago del Estero prov., Ojo de Agua, 15-I-1980, Woodruff - De Loach, 1 male, 3 females, UV light trap; La Rioja prov., Chilecito, 29-IX-1989, G. Spinelli, 4 males, at light.

Distribution. Dominica, Colombia, Brazil, northern Argentina (Salta, Santiago del Estero and La Rioja provinces).

\section{Forcipomyia $(F$.$) quatei Wirth$}

F. (F.) quatei Wirth, 1952: 142 (male, female; USA); Wirth, 1982: 576 (female, male redescr., pupa, larva; Belize, Dominica, Costa Rica, Panama, Ecuador, Brazil); Borkent and Spinelli, 2000: 15 (in Neotropical catalog; distrib.). 
Specimens examined. Argentina, Misiones prov., Cuñapirú stream, 18/19-V-1997, J. Williams, 1 female, at light; Entre Ríos prov., Salto Grande, Puerto Luis, 9-XI-1984, G. Spinelli, 1 female. Paraguay, Itapúa, Bella Vista, 13-VIII-1998, G. Spinelli, 1 female, same data except, 13-VII-1999, 1 male, CDC.

Distribution. From USA to Brazil, Paraguay and northeastearn Argentina (Misiones and Entre Ríos provinces).

\section{RESUMEN}

Se describe e ilustra una especie nueva del grupo Forcipomyia (Forcipomyia) argenteola, F. $(F$.) donatoi, sobre la base de machos y hembras capturados en diversas localidades del norte de Argentina y Paraguay. Esta especie es comparada con $F$. (F.) marini y $F$. (F.) uramaensis, ambas de Venezuela, con las cuales presenta semejanzas morfológicas. Las especies Forcipomyia $(F$.) argenteola, $F$. $(F$.) calatheae y $F$. $(F$.) quatei se registran por primera vez en Argentina, y se provee, además, una clave para la identificación de las siete especies Neotropicales del grupo.

Palabras clave: grupo Forcipomyia argenteola, especie nueva, nuevos registros, clave, región Neotropical.

\section{REFERENCES}

Borkent, A. \& G.R. Spinelli. 2000. Catalog of the New World biting midges south of the United States of America (Diptera: Ceratopogonidae). Contrib. Entomol. Internat. 4: 1-107.

Lane, J. 1947. A biologia e taxonomia de algumas especies dos grupos Forcipomyia e Culicoides (Diptera:
Ceratopogonidae) (Heleidae). Arq. Fac. Hig. Saude Pub. Univ. São Paulo 1: 159-170.

Macfie, J.W.S. 1939. A report on a collection of Brazilian Ceratopogonidae (Dipt.). Rev. Ent. 10: 137-219.

Martínez, A., Z. Narváez \& G.R. Spinelli. 2000. Mosquitas polinizadoras (Diptera: Ceratopogonidae) del cacao colectadas en comunidades Piaroa en Amazonas, Venezuela. Bol. Entomol. Venez. 15: 249-253.

McAlpine, J.F., B.V. Peterson, G.E. Shewell, H.J. Teskey, J.R. Vockeroth \& D.M. Wood. 1981. Manual of Nearctic Diptera. Volume 1. Ottawa, Agriculture Canada Monograph 27. 674 p.

Spinelli, G.R. \& A. Dippolito. 1995. Two new Neotropical species of the Forcipomyia $(F$.) argenteola species group (Diptera: Ceratopogonidae). Rev. Soc. Entomol. Argent. 54: 155-158.

Szadziewski, R. 1996. Biting midges from Lower Cretaceous amber of Lebanon and Upper Cretaceous Siberian amber of Taimyr (Diptera: Ceratopogonidae). Studia Dipterol. 3: 23-86.

Winder, J.A. 1977. Field observations on Ceratopogonidae and other Diptera: Nematocera associated with cocoa flowers in Brazil. Bull. Entomol. Res. 67: 57-63.

Wirth, W.W. 1952. The Heleidae of California. Univ. Calif. Publ. Entomol. 9: 95-266.

Wirth, W.W. 1982. The cacao-pollinating midges of the Forcipomyia argenteola group Diptera: Ceratopogonidae). Proc. Entomol. Soc. Wash. 84: 568-585.

Young, A.M. 1986. Notes on the distribution and abundance of midges (Diptera: Ceratopogonidae and Cecidomyiidae) in some Central American cacao plantations. Brenesia 0 (24): 273-286, 